\title{
Cesarean Section: One of the Oldest and Controversial Surgical Procedures
}

\author{
Liliana Strat ${ }^{1}$, Alin Vasilescu ${ }^{2 *}$ and Victor Strat $^{2}$ \\ ${ }^{1}$ Gynecology and Obstetrics Hospital Cuza Vodă lași, Romania \\ ${ }^{2}$ Department of Surgery, St. Spiridon Hospital, University of Medicine and Pharmacy Gr. T. Popa lasi, Romania
}

\begin{abstract}
The idea of the possibility of childbirth in another route than natural still exists from mythology. The name derives from the Latin "caedere" - cut, sever. For many centuries, ever since the Roman Empire, the operation was performed only rarely and women who died in childbirth. Indications that cesarean would be performed even women are living since 1040 in Rabbi Gershon to Metz, Talmud's comment. In 1581 the first paper appears in France dedicated caesarean women live, but the first successful Caesarean operation are reported in France, only in 1689 from surgeon Jean Rulau, in Ireland 1748 from midwife Marie Donaly and in 1794 in Virginia (USA) from the country doctor Jesse Bennett. Mortality after cesarean on women living it was still very high. A significant decrease occurred in the 19th century it when decline spectacular after improvements are made of the operation. Mainly this is due to Frank E. Polin in US, Alfred Kehrer in Heidelberg, Max Sänger in Leipzig and Eduardo Porro in Milan. Their refinements of the technique were essential cesarean bringing a lot of one that is currently running. Classical caesarean is practiced today after Stark technique, method Joel Cohen. After a long and controversial trend for nearly two millennia, marked for centuries by almost prohibitive mortality, the current cesarean operation is a great success in perseverance deeply humanitarian attempts to save two lives, a mother and child.
\end{abstract}

Keywords: Caesarean section; Morbidity and mortality; Surgical technique; History of medicine

S-au găsit datând încă din preistorie, schelete de femei care din cauza unor distocii grave de bazin au murit la naștere, iar fătul a rămas captiv în bazinul acesteia. Ideea posibilității aducerii pe lume a unui copil și pe altă cale decât cea naturală o aflăm încă din mitologie. Astfel, zeul Apolo ca răzbunare pentru infidelitatea iubitei sale pământene Coronis cu care zeul zămislise un copil, îi decide moartea. Înainte ca aceasta să fie cuprinsă de flăcări la incinerare, zeul, cuprins de remușcări, își extrage fiul încă viu din trupul mamei moarte. Acest fiu va fi Asclepios, zeul medicinei. Însuși Zeus și-ar fi extras progenitura, pe Dionisos, din trupul lui Semele, decedată înainte de termen. Din acest motiv, Dionisos a trebuit ca un timp, pentru a se matura, să fie ținut în coapsa lui Zeus. În mitologia persană, în "Cartea Regilor”, se arată că prințesa Radabeh, soția lui Javal, având la naștere un travaliu lung și dificil, soțul acesteia cere ajutorul unei păsări mitice Simurg care îl învață cum să-și extragă copilul din abdomenul mamei. Acesta va fi Rostan, un erou legendar. În mitologia indiană, prințesa Maya l-ar fi adus pe lume pe Buddha direct din flancul drept al abdomenului. Brahma, s-ar fi născut și el direct din ombilicul mamei sale [1,2].

Într-un fel sau altul s-a observat totuși că viața unui făt putea fi salvată prin extragerea sa direct din abdomenul unei mame decedate la naștere. $\mathrm{Nu}$ întâmplător în anul 600 î.Hr., sub domnia lui Numa Pompilius (762-615 îHr.) s-a emis o lege "lex regia" (legea regală), prin care se interzicea îngropare unei gravide la sfârșitul sarcinii înainte de a i se fi extras fătul. Cel ce nu ar fi procedat în acest fel se arată în "Digesta" lui Justinian este considerat că a lăsat să se piardă odată cu mama și o speranță de viață. "Lex regia" a fost aplicată și sub domnia împăraților - a cezarilor sub numele "lex caesarea". Nașterea abdominală a primit și ea numele de "partus caesarea"[2].

Mult timp s-a crezut că numele de cezariană ar fi legat de cel al lui Iulius Cezar (100-44 î.Hr.) considerându-se că prin această operație ar fi fost adus el pe lume. Fapt inexact, deoarece mama lui, Aurelia, nu a murit la naștere, având ulterior și alte nașteri. $\mathrm{O}$ ipoteză preluată după Pliniu îl implică pe Publius Cornelius Scipio zis Africanul (235-
183 Î. Hr.) a cărui mamă a murit la naștere, nereușind să-și aducă fiul pe lume. "A trebuit să i se incizeze abdomenul pentru a-l salva viu" arată Pliniu. Ulterior Scipio a primit numele de Cezar și e posibil ca operația să fi primit de la acesta numele de cezariană. S-a mai presupus că denumirea ar deriva din latinescul "caedere" - a tăia, a secționa [2].

Timp de multe secole operația s-a practicat foarte rar şi doar pe femei decedate la naștere. Guy de Chauliac (1298-1382) recomanda la timpul său ca incizia să fie făcută în flancul stâng al abdomenului pentru a evita ficatul. În secolele 14 și 15 apar în Franța dar și în Orient, o serie de miniaturi și gravuri care ilustrează scene de extragere din abdomenul mamei decedate a unui făt viu. În secolul următor sunt autori cum de exemplu Suetoniu (1506), Charles Estienne (1545), Ronssens (1539), Ryff (1582) care, în tratatele lor, se referă și la această operație [2]. Ei îi discută indicațiile, sediul inciziei (mediană, în flancul drept sau curbilinie în stânga) precum și instrumentarul necesar. Între timp apar însă indicii că cezariana s-ar fi efectuat încă mai demult chiar și pe femei vii. În anul 1040 în comentarile la Talmud ale rabinului Gershon din Metz se susține acest fapt. În secolul 16 apar însă gravuri care vin să confirme ipoteza. Astfel în 1596 în cartea sa "La commare", Scipione Mercurio, anatomist și chirurg militar italian, probabil și mamoș, exemplifică cu imagini pozițiile ce trebuiesc date femeilor la naștere pentru cezariană; dacă starea femeii este bună, recomandă poziție semișezândă, bine sprijinită, iar dacă dimpotrivă femeia este foarte slăbită, poziție de decubit. Este însă puțin probabil

*Corresponding author: Vasilescu Alin, Department of Surgery, St Spiridon Hospital, Str. Independentei, No 1, lasi, Romania, Tel/Fax: +40 (0) 2182 72;E-mail: vasilescu.alin@gmail.com

Received May 4, 2015; Accepted May 20, 2015; Published May 27, 2015

Citation: Strat L, Vasilescu A, Strat V. [Cesarean Section: One of the Oldest and Controversial Surgical Procedures] Journal of Surgery [Jurnalul de chirurgie]. 2015; 11(1): 355-357 DOI:10.7438/1584-9341-11-1-10 [article in Romanian]

Copyright: (c) 2015 Strat L, et al. This is an open-access article distributed under the terms of the Creative Commons Attribution License, which permits unrestricted use, distribution, and reproduction in any medium, provided the original author and source are credited. 
ca Mercurio, călugăr fiind, să fi executat el însuși o astfel de operație. $\mathrm{O}$ gravură care ilustrează deasemeni sugestiv efectuarea cezarienei pe o femeie vie o găsim într-un tratat apărut postum în 1683 a lui Scultetus din Germania. Tot din această perioadă există însă și relatări directe de observații de cezariene realizate pe femei vii și ceea ce este surprinzător, cu succes atât pentru mamă cât și pentru copil. O primă relatare din 1581 aparține anatomistului elvețian Bauhin. El susține că în anul 1500 într-un canton din Elveția un anume Jacob Nufer care se ocupa de castrarea porcilor, disperat fiind că soția sa nu reușea să nască după un travaliu lung și obositor, cere permisiunea autorităților şi intervine el însuși. Incizează abdomenul mamei din care extrage un copil viu; suturează apoi peretele. Soția a mai purtat și alte sarcini, iar copilul a trait mulți ani. $\mathrm{O}$ a doua observație de cezariană pe femeie vie datează din 1610. Ea a fost executată de doctorul JeremiahTrautmann din Wittenberg pe soția unui butnar, care, gravidă fiind, a fost lovită puternic în abdomen de un cerc de butoi. Chirurgul intervine și extrage un copil viu. După o perioadă bună, mama moare însă în a 25-a zi. Copilul a trăit până la 9 ani. E aproape incredibilă însă o relatare din 1647 în care soția gravidă, a unui fermier din Olanda, este împusă în abdomen de un taur înfuriat. Din plagă a putut fi salvat copilul viu dar mama a murit [3].

În 1581 apare în Franța prima lucrare dedicată cezarienei pe femei vii. Ea aparține medicului parizian Francois Rousset care a intitulat-o “Traite Nouveau de l'Hystérotomotokie ou Enfantement caesarien”. În lucrare Rousset arată că "extragerea unui copil prin incizie laterală a abdomenului și a uterului la o persoană gravidă şi care nu poate să nască altfel, nu prejudiciază viața nici a unuia nici a altuia și nu împiedică după aceea fecunditatea maternală". În tratat, autorul, care de fapt nu a executat personal această operație, îi dă numele de cezariană. El adună inițial un număr redus de observații, între care include și observația relatată de Bauhin. Într-o ediție ulterioară în latină, mai amplă, autorul adună noi cazuri. Avizul pentru publicarea cărții lui Rousset a fost dat de Ambroise Pare. A practicat el însuși împreună cu Jacques Guillimeau această operație pe un număr de cazuri dar având numai eșecuri își retractă susținerea [4].

Timp de aproape 2 secole cezariana pe femei vii nu a mai fost executată decât foarte rar: mortalitatea era de de 80-90\%. Supraviețuirile constituiau o excepție. Se notează de exemplu o singură supraviețiure pe 24 cezariene. Cele mai multe femei operate mureau fie imediat de hemoragie, fie la o săptămână de infecție. Lipsa de reluare a tonicității uterului mai ales după un travaliu lung, favoriza hemoragia. Mult timp, plaga uterină nu a fost suturată. Abia în 1769, Lebas o suturează cu trei fire de mătase. Firele erau lăsate lungi, ieșind din plagă, pentru a putea fi scoase mai ușor. Infecția și peritonita erau inevitabile. Alain Espessat arată că la Paris în perioada 1740-1787 s-au înregistrat doar 6 succese față de 25 eșecuri. Mortalitatea, mai ales în clinicile universitare, ajunsese de necrezut, între 50 și 100\%. Rarele succese se înregistrau mai curând în spitale mici sau chiar în mediul rural. Marii obstreticieni ai timpului practicau cezariana dar numai pe femei decedate. Foarte reticenți nu excludeau cezariana pe femei vii, arătându-i însă șansele minime. Ei stabilesc indicațiile cezarienei în orice situație, inciziile de preferat și instrumentarul necesar [4].

În fața numărului atât de mare de insuccese se constituie în 1791 la Paris o Societate anticezariană condusă de Jean Sacombe, societate care edita și un ziar propriu. Pe de altă parte se manifestă un alt curent din partea unor clerici foarte fervenți, ca de exemplu episcopul și inchizitorul de Sicilia F. E. Cangiamila, de a impune ca obligatorie cezariana pe femei moarte în vederea unui eventual botez al copilului. Regele Carol al III-lea al Spaniei emite în 1748 un edict prin care se oferă indulgențe în cazul efectuării unei cezariene sau dimpotrivă, amenințarea cu moartea în caz de refuz. În această perioadă atât de fierbinte asistăm totuși și la succese privind cezariana pe femei vii. În Franța în 1689 este realizată prima cezariană cu succes de către chirugul
Jean Rulau. Mama a supraviețuit dar copilul a murit după 2 zile. În Irlanda în 1748, moașa Marie Donaly execută cezariana printr-o incizie transversală, folosind un simplu brici. Ea sutureaza plaga cu ațe și ace aduse pe loc de la un croitor. Atât mama cât și copilul au fost salvate. Un dublu succes este înregistrat în anul 1794 în statul Virginia (SUA), când medicul de țară Jesse Bennett prectică cezariana pe propria soție în condiții de țară dintre cele mai grele, pe o masă improvizată, dar cu succes. $\mathrm{Nu}$ însemnă că mortalitatea după cezariene pe femei vii nu era încă foarte mare. $\mathrm{O}$ scădere importantă a acesteia s-a produs abia în perioada imediat premegătoare secolului 19 când scade spectaculos de la 80 la $22 \%$. Aceasta se produce când încep să fie aduse îmbunătătiri ale operației. În 1882 Frank E. Polin din SUA execută sutura plăgii uterine cu fire de argint. La fel s-a procedat și în alte 16 cezariene. O scădere cu totul importantă a mortalității se produce însă în sec. XIX când ea ajunge la 8 și chiar 3\%. În principal aceasta se datorează unor doi mari pioneri: Alfred Kehrer din Heidelberg și Max Sänger din Lepzig. Perfecționările lor privind tehnica cezarienei au fost esențiale apropiind-o mult de cea care se execută în prezent [2,5].

Alfred Kehrer recomandă ca incizia uterină să fie transversală, segmentară, urmată de o sutură cu multă grijă și totul în condiții de asepsie. El practică această operație la 25 septembrie 1881, noapte în condiții grele de țară dar obținând un dublu succes. $\mathrm{O}$ a doua operație efectuată în clinică universitară a fost în schimb un total eșec. Max Sänger este cel care 1882 a mai practicat cezariana prin incizie corporeală longitudinală clasică. Suturează uterul cu fire de argint. Tehnica a fost urmată cu succes în același an de Leopold și în Franța, de Bart în 1884.

Propuneri pentru efectuarea unei incizii segmentare joase a uterului au fost făcute cu mult înainte. Printre aceștia se înscriu R.W. Johnson în 1780, Osander în 1805, Rigen în 1820 sau J. A. Baudeloque în 1823. Propunerile nu au fost însă luate în seamă. O altă propunere deasemenea neaplicată o face în 1819 Charles Bell. El recomandă o incizie mică pe segmentul inferior al uterului și care să fie lărgită prin dilacerare digitală. Ideea a fost reluată de Blundel în 1834 dar fără succes. O operație care a făcut epocă a fost realizată în 1876 de Eduardo Porro din Milano. În cursul cezarienei la o gravidă de 25 ani cu bazin rahitic foarte îngust, Porro este confruntat cu o hemoragie uterină de nestăpânit. Sub hemostază provizorie a uterului el practică odată cu cezariana și histerectomie subtotală salvatoare atât pentru mamă cât și pentru copil. Operația îi va purta numele. Succese au mai fost obținute în 1879 în Franța de Fochier si Tarnier. Un număr de ani, cezariana Porro a fost efectuată în paralel cu cezariana clasică, dar mortalitatea foarte mare chiar și de $50 \%$ a făcut să fie părăsită [4].

Cezariana clasică este practicată azi după tehnica Stark, metoda Joel Cohen cu incizie suprapubiană și histerotomie segmentară transversală joasă.

După o lungă și controvesată evoluție de aproape două milenii, marcată timp de secole de o mortalitate aproape prohibitivă, cezariana actuală reprezintă un mare succes în perseverența încercărilor profund umanitare de a salva două vieți, a mamei și a copilului în situația unor dificultăți majore la naștere. Beneficiul pentru mame s-arătat enorm, mai ales că cezariana a ajuns să constituie astăzi o operație din cele mai sigure cu o mortalitate de $0,012 \%$ [5]. S-a ajuns ca în unele medii sociale să se manifeste din partea femeilor gestante o tendință preferențială, nu întotdeauna justificată, pentru nașterea prin cezariană, operație care în trecutul îndepărtat era practicată doar în condiții extreme.

\section{Conflict de interese}

Autorii nu declară niciun conflict de interese.

\section{Bibliografie}

1. Speert H (1976) Histoire illustrée de la gynécologie et de l'obstétrique. Roger Dacosta (Ed), Paris. 
2. Espesset A (2010) Césarienne des histoires dans l'histoire. $7^{\circ}$ Congres de Gynecologie Obstetrique \&Reproduction de la Côte d'Azur.

3. Pecker A, Roulland H (1958) L'accouchement au cours des siècles. Roger Dacosta (Ed), Paris.
4. Dumont M, Morel P (1968) Histoire de l'gynecologie et de la obstretique, Lyon, (Éd), Simep. 1968.

5. Todman D (2007) A history of caesarean section: from ancient world to the modern era. Aust N Z J Obstet Gynaecol 47: 357-361. 